\title{
A New Orchid species of the genus Brassavola (§ Cuneilabia) from the west Indian Island of Jamaica
}

\author{
H. G. JONES
}

The new species of Brassavola described below turned up among a collection of seventeen specimes belonging to this genus, which were made available to the writer by the University of the West Indies for the purpose of preparing a monograph of the genus; the name Brassavola Harrisii honours the collector of the specimen which we have selected as the type of the new species. B. Harrisii is a fairly typical member of Brassavola § Cuneilabia: its closest ally appears to be B. subulifolia, from which it may be easily distinguished by its more robust habit, the coarse, manyflowered scape, somewhat larger flowers, and proportionately longer claw of the lip - the length of which in B. Harrisii exceeds one half length of the entire lip.

The artificial key to the species which comprise Brassavola $\S$ Cuneilabia, given below, is followed by a formal description of B. Harrisii and a few brief notes on the related species. B. Harrisii is the second novelty of Brassavola § Cuneilabia to be recognized from the West Indies since the commencement of our studies on the genus; the first was B. Gillettei, from Trinidad, which we published recently in the Boletim da Sociedade Broteriana, Vol. 41 (1967). The discovery of these two species appears to exemplify one aspect in the development of the Caribbean flora which has recently been commented upon by Dr. C. L. Withner in the course of describing two new Orchid species of the genus Oncidium from Hispaniola. "One wonders, sometimes," writes Dr. W it h n e r, "whether all such plants are really new species and have actually escaped detection on the relatively welltraveled and collected islands of the Caribbean." He then goes on to add, however, that the highly localized and endemic nature of many of these species is a very important factor, which must be taken into consideration.

\section{KEY TO THE SPECIES OF BRASSAVOLA § CUNEILABIA}

1. Inflorescence terminal.

2. Flowers less than $6.5 \mathrm{~cm}$ in diameter

B. subulifolia

2. Flowers more than $6.5 \mathrm{~cm}$ in diameter.

3. Inflorescence $14-16$ flowered

B. Harrisii

3. Inflorescence $2-6$ flowered. 
4. Flower-scape longer than the leaf

B. Gillettei

4. Flower-scape shorter than the leaf.

5. Flowers less than $12 \mathrm{~cm}$ in diameter.

6. Inflorescence branched

B. rhopalorrhachis

6. Inflorescence simple.

7. Margin of lip entire

B. nodosa

7. Margin of the lip broken

B. venosa

5. Flowers more than $12 \mathrm{~cm}$ in diameter

B. grandiflora

1. Inflorescence lateral

B. acaulis

Brassavola Harrisii H. G. Jones, sp. nov.

Species affinis B. subulifoliae a qua scapo crasso longiore, racemo dense mulitfloro et floribus paulo majoribus facile distinguitur. Herba epiphytica, erecta vel suberecta, usque ad $45 \mathrm{~cm}$ alta; radicibus filiformibus, flexuosis, glabris; rhizomate brevi, decumbente, inter caules circa $2 \mathrm{~cm}$ longo; caulibus rigidulis, teretibus, unifoliatis, circa $15 \mathrm{~cm}$ longis, medio circa $9 \mathrm{~mm}$ diametribus; vaginis 3 alte et arcte amplectentibus, circa 5.5, 8 et $11.15 \mathrm{~cm}$ longis, apice acutis; folio subtereto vel anguste elliptico, sulcato, apice acuminato, circa $30 \mathrm{~cm}$ longo, circa $1 \mathrm{~cm}$ lato; scapo crasso erecto, floribus inclusis quam folio paulo breviore, circa $22 \mathrm{~cm}$ longo, circa $5 \mathrm{~mm}$ diametro; racemo circa $7.5 \mathrm{~cm}$ longo, 14-16 floro; bracteis parvulis triangulis, apice acuminatis, ovario pedicellato multoties brevioribus, circa $8 \mathrm{~mm}$ longis, explanato circa $7 \mathrm{~mm}$ lato; ovario cum pedicelo gracili glabro, circa $3.5 \mathrm{~cm}$ longo. Flores expansi circa $8 \mathrm{~cm}$ diametro: sepalis linearibus, acuminatis, circa $4 \mathrm{~cm}$ longis, circa $4 \mathrm{~mm}$ latis, lateralibus obliquis; petalis quam sepala paulo brevioribus et angustioribus, anguste linearis, acuminatis, circa $3.8 \mathrm{~cm}$ longis, circa $2 \mathrm{~mm}$ latis; labello circa $3.3 \mathrm{~cm}$ longo, parte basilari angustato, circa $1.8 \mathrm{~cm}$ longo, explantao circa $8 \mathrm{~mm}$ lato, parte anteriore late cordato, circa $1.5 \mathrm{~cm}$ longo, circa $1.6 \mathrm{~cm}$ lato, apice subacuto; columna sectionis, circa $7 \mathrm{~mm}$ longa, circa $3 \mathrm{~mm}$ lata; anthera et pollina generis; capsula circa $3.5 \mathrm{~cm}$ longa, medio circa $1.5 \mathrm{~cm}$ diametro, apice rostrata.

$\mathrm{R}$ a $\mathrm{n}$ g e: Jamaica, apparently endemic.

Material examined: W. Harris No. 10,451, Troy, 1600 feet altitude, on trees, 14.9.1906 (Type); W. Harris No. 7661, Belvidere, Hanover, 500 feet altitude, growing on trees, 12.1 .99 (fruiting specimen); Wm. Harris and N. L. Britton No. 10,626, Near Mandeville, on trees, 23 Sept. 1908; Lady Blake (s. n.), Mandeville, (18)90.

Note: All four of these specimens are in the herbarium of the University of the West Indies in Jamaica and were originally labeled "Brassavola cordata Lindl."

In the course of investigating the concept known as Brassavola cordata, it became evident that over the years this name had been used to 
cover two distinct elements, which - very broadly speaking - might be delimited thus: Type A, a small plant, bearing short racemes of 3-8 flowers: and Type $B$, a much larger and more robust plant, bearing elongated racemes of $14-16$ flowers. Type $A$ agreed fairly well with the original specimen of $B$. cordata in Lindleys's herbarium; so we concluded - or rather, hoped - that Type $B$ represented the earlier concept known as B. subulifolia. Unfortunately, the original type of this species appears to have been lost; but upon checking the published description, we found that the diagnostic characters set out by Lindley, especially "spicâ pauciflorâ", clearly seperated this species from our Type B. It seemed evident, therefore, that Rolfe and Schlechter were justified in treating $B$. subulifolia* as the correct name for the plant more widely known as $B$. cordata; and that our Type $B$ represented a hitherto undescribed species.

Inasmuch as we have so far seen only dried specimens of the new species, it is impossible to give any details concerning the colour of the living flowers in B. Harrisii. There is, however, no reason to suspect that these differ in colour from the other species of the genus, which are almost totally uniform in this respect; having pale greenish or yellowish sepals and petals, with a white or cream-coloured lip. The only exceptions to this rule are B. tuberculata and its South American allies of ssp. Brassavola, in which a few purple or brownish-purple spots are found on the perinanth segments.

In our preliminary review of the genus Brassavola, we gave the total number of species for the ssp. Cuneilabia as 6; but as a result of subsequent investigations, we have decided to recognize $B$. venosa as distinct from $B$. nodosa because of its somewhat differently shaped lip. On the basis of the material which we have examined, we have also decided to recognize the large-flowered $B$. grandiflora as distinct from $B$. nodosa. Schlechter apparently realized the difference between these two taxa; but appears to have based his conception of B. nodosa on the largeflowered plant plant and to have described the smaller one as a new species under the name B. scaposa. Since the latter corresponds fairly well with the original Plumier plate which is the lectotype of B. nodosa, we have decided to follow Dr. L. O. Willi a m s in treating B. scaposa as a synonym of $B$. nodosa. In the true $B$. nodosa, the length of the perinanth segments never exceeds $6 \mathrm{~cm}$; whereas in $B$. grandiflora, these usually measure $6-7 \mathrm{~cm}$ in length.

The 8 species which comprise Brassavola ssp. Cuneilabia, as we understand it, may in turn be divided into two smaller subsections or

* We also include here the plant described as B. Sloanei by Grisebach (1864), the type specimen of which is preserved in the herbarium of the Royal Botanic Gardens, Kew. 
alliances, as follows: (a) the "Subulifolia Alliance", consisting of B. subulifolia and B. Harrisii; and (b) the "Nodosa Alliance", consisting of the 6 remaining species. Although, superficially, B. acaulis appears to be amply distinct from all the other species of this section by reason of the lateral form of the inflorescence, in point of floral details, this species is very close to $B$. nodosa.

In some respects, $B$. Gillettei appears to provide the connecting link between B. nodosa and B. rhopalorrhachis. Actually, the difference between the two last named taxa is easier to percieve than to put into words; but no one who has had the opportunity of comparing the living plants in flower could fail to appreciate the distinctiveness of $B$. rhopalorrhachis. The individual flowers are very similar to those of $B$. nodosa, especially in dried herbarium material, but the short pedicels make them appear very closely packed on the tops of the short racemes, which lends the inflorescence a courious resemblance to that of the genus Leptotes. This resemblance is considerably strengthened by the fact that in some forms of B. rhopalorrhachis, the sepals and petals of flowers which have been open for several days often assume a slight but distinct pinkish hue. The relatively stout, rigidly erect flower scape, branched at the summit, and often with the base nearly completely concealed within the channel of the leaf, is also rather distinctive in this species.

The artificial key and the discussion of the species of Brassavola ssp. Cuneilabia, given above, is provided as supplementary data in the hope that this may be of some assistance in clarifying the systematic position of the new species. The addition of B. Harrisii brings the total number of Brassavola species found in Jamaica up to four - the other three being B. subulifolia, B. nodosa and B. grandiflora. The herbarium of the University of the West Indies also posseses a specimen from cultivated material of the Middle American endemic species, B. glauca (ssp. Grandiflorae).

\section{ACKNOWLEDGEMENTS}

We should like to take this opportunity of recording our thanks to Dr. C. D. A d a m s, senior lecturer in botany at the University of the West Indies, who kindly arranged the loan of the material mentioned at the beginning of this paper. Our thanks are also due to the Director of the Naturhistorischen Museums' Botanische Abteilung in Vienna, who made available on loan the type sheet of B. rhopalorrhachis from Reichenbach's herbarium; and to Sir George Taylor, Director of the Royal Botanic Gardens, Kew, who provided excellent photographs of the surviving types of the species described by Grisebach, Hooker and Lindley. 


\section{BIBLIOGRAPHY}

Grisebach, A. H. R. (1864). Flora of the British West Indian Islands. London. J on es H. G. (1967). Preliminary Contribution towards a Revision of the Genus

Brassavola R. Br. of the Orchidaceae. Boletin da Sociedade Broteriana. Vol. 41. Lind le y J. (1830-40). Genera and Species of Orchidaceous Plants. London. Reichenbach H. G. (1852). Gartenorchideen IV. Botanische Zeitung. 10. Rolfe R. A. (1902). The Genus Brassavola. The Orchid Review. 10. Schlechter R., (1919). Die Gattung Brassavola R. Br. Orchis. 13. Williams L. O., (1956). An Enumeration of the Orchidaceae of Central America, British Honduras and Panama. Ceiba. 5.

Withner C. L., (1967). Two New Equitant Oncidiums from Hispaniola. American Orchid Society Bulletin. 36. 